\title{
Virulence properties of atypical EPEC strains
}

\author{
J. S. PELAYO, I. C. A. SCALETSKY*, M. Z. PEDROSO*, V. SPERANDIO, J. A. GIRÓNं, \\ G. FRANKEL $\ddagger$ and L. R. TRABULSI
}

Departamento de Microbiologia, Universidade de São Paulo, 05508-900 São Paulo, *Departamento de Microbiologia, Imunologia e Parasitologia, Universidade Federal de São Paulo/Escola Paulista de Medicina, 04023-062 São Paulo, Brazil, + Centro de Investigaciones en Ciencias Microbiologicas, Benemerita Universidad Autonoma de Puebla, 72570 Puebla, México and $\$$ Department of Biochemistry, Imperial College of Science, Technology, and Medicine, London SW7 2AZ, UK.

\begin{abstract}
Virulence properties of 31 atypical enteropathogenic Escherichia coli (EPEC) strains isolated from cases of diarrhoea were examined. All except two strains adhered to HEp2 cells in a localised adherence-like (LAL) pattern. With the exception of two strains, all were fluorescent actin staining (FAS) positive. Gentamicin HEp-2 invasion assay studies showed that all strains were invasive. Transmission electron microscopy of infected HEp2 cells showed the characteristic attaching and effacing lesion and invasion of the cultured cells. Of the nine strains that hybridised with a DNA probe for $\alpha$-haemolysin, five were haemolytic within $3 \mathrm{~h}$ of incubation, while the remaining strains were haemolytic only after incubation for $24 \mathrm{~h}$. Three strains produced enterohaemolysin on blood agar. None of the 31 strains of $E$. coli induced fluid accumulation in the rabbit intestinal loop assay or displayed cytotoxic effects in HeLa and Vero cells. All the strains belonging to serotypes $\mathrm{O26}: \mathrm{H11}, \mathrm{O} 26: \mathrm{H}^{-}$and $0119: \mathrm{H} 2$ expressed intimin $\beta$, whereas all the strains from serotype 055:H7 expressed intimin $\gamma$. The strains belonging to serogroup 0111 expressed a non-typable intimin. The participation of intimin in LAL was supported by adhesion inhibition experiments in which antibodies to intimin significantly reduced the level of LAL.
\end{abstract}

\section{Introduction}

Enteropathogenic Escherichia coli (EPEC) remains a leading cause of infantile diarrhoea worldwide. The exact mechanisms by which EPEC strains cause diarrhoea are unknown, but one important characteristic of the histopathology of the infection is attaching and effacing (A/E) lesion. All A/E-positive bacteria have a $35-\mathrm{kb}$ chromosomal pathogenicity island, called the LEE region (for locus of enterocyte effacement), that appears to encode all the necessary functions required for $\mathrm{A} / \mathrm{E}$ lesion formation $[1,2]$. Proteins encoded by the LEE region can be divided into three functional groups: (1) Sep, involved in a type III secretion apparatus [3]; (2) Esps, secreted proteins involved in cell signalling [4-6]; and (3) intimin, a 94$\mathrm{kDa}$ outer-membrane protein associated with intimate bacterial adhesion and re-arrangement of cytoskeletal actin [7]. Intimin is encoded by the gene eae, which

Received 20 Jan. 1998; revised version accepted 13 April 1998.

Corresponding author: Dr J. S. Pelayo. has been cloned and sequenced from human EPEC [8], human enterohaemorrhagic E. coli (EHEC) [9, 10], and Hafnia alvei (C-terminus only) [11], as well as from Citrobacter freundii $[11,12]$. In their amino acid sequence, intimins show $>90 \%$ homology over the first 659 amino acid residues, but less homology over the remaining 280 residues at the $\mathrm{C}$-terminus of the protein. Frankel et al. $[11,13]$ have demonstrated that the binding activity of intimin is located at the $\mathrm{C}$ terminus of the protein. Polymerase chain reaction (PCR) and serological tests for intimin classification have been developed, based on the eae gene sequences of EPEC O127:H6, O114:H2 and O86:H34 and EHEC O157:H7. Recently these tests showed that intimin polypeptides can be divided into at least five serologically distinct types, designated intimin $\alpha, \beta, \delta$ and $\gamma$, respectively and a non-typable group [14].

Gómez and Kaper [15] described a cluster of genes $(\operatorname{per} \mathrm{A}, \mathrm{B}, \mathrm{C})$ that regulate expression of eae and are located in a $60-\mathrm{MDa}$ plasmid referred to as the EPEC adherence factor (EAF) plasmid. The EAF plasmid also harbours the bundle-forming pilus ( $b f p$ ) gene cluster [16] and is widely distributed among EPEC 
strains, as demonstrated by hybridisation with a DNA probe derived from EAF plasmid (EAF probe). The EAF plasmid is not essential for the A/E phenotype, as strain E2348/69 cured of EAF plasmid can still cause A/E lesions, albeit with less efficiency [17].

A new class of diarrhoeagenic $E$. coli was recently described and regarded as atypical EPEC strains, because they are positive for eae but do not have the EAF plasmid which is detected by the EAF probe [18]. Atypical EPEC strains are found in several EPEC $O$ serogroups and correspond to serotypes or electrophoretic types (ETs) different from those of typical EPEC strains [19-22]. These bacteria are frequently isolated from individuals with diarrhoea in which no other pathogen can be identified. In the UK, EPEC strains not hybridising with the EAF probe may be of greater importance than the EAF-positive strains [23]. Whether atypical EPEC strains possess additional virulence factors that have yet to be discovered or whether there are specific host factors that predispose to disease with these strains is unknown [18].

The aim of this study was to investigate further the virulence characteristics of some atypical EPEC strains of serogroups $\mathrm{O} 26, \mathrm{O} 55$ and $\mathrm{O} 111$. O119:H2 strains that contain the $b f p A$ and $\operatorname{per} A$ genes but do not hybridise with the EAF probe were also included in the study.

\section{Materials and methods}

\section{Bacterial strains}

The study investigated 25 atypical EPEC strains of serogroups O26, O55 and O111 and also studied six strains of $E$. coli O119:H2 that contain plasmidencoded $b f p A$ and perA genes, but do not react with the EAF probe and do not produce the bundle-forming pilus (BFP). All the strains included in this study were isolated from patients with diarrhoea and previously characterised as regards serotype, electrophoretic types (ETs) and virulence genes [19-22]. After isolation, the strains were kept on nutrient agar protected from light. Strain number, serotype, ET, virulence genes, isolation period and origin are shown in Table 1. Bacterial strains used as controls and for other purposes in this study are listed in Table $2[8,15,24-26]$.

\section{Antisera}

Polyvalent antisera raised against the whole $94-\mathrm{kDa}$ intimin purified from JPN15 harbouring pCVD450 which carries the entire per genes and overexpresses

Table 1. Serotype, electrophoretic types, virulence genes, period of isolation and origin of the atypical EPEC strains

\begin{tabular}{|c|c|c|c|c|c|}
\hline Strain no. & Serotype & ET & Virulence genes & Period of isolation & Origin \\
\hline $2262-79$ & $\mathrm{O} 26: \mathrm{H}^{-}$ & 13 & eae, $\alpha-H l y$ & 1979 & USA \\
\hline C240-52 & $\mathrm{O} 26: \mathrm{H}^{-}$ & 13 & $e a e, \alpha-H l y$ & 1952 & Switzerland \\
\hline C814-67 & O26:H11 & 13 & $e a e, \alpha-H l y$ & 1967 & Denmark \\
\hline $3323-61$ & $\mathrm{O} 26: \mathrm{H} 11$ & 13 & $e a e, \alpha-H l y$ & 1961 & USA \\
\hline 15 & $\mathrm{O} 26: \mathrm{H} 11$ & 1 & $e a e$, EHEC & 1985 & Brazil \\
\hline 20 & $\mathrm{O} 26: \mathrm{H} 11$ & 15 & eae, EHEC & 1986 & Brazil \\
\hline 22 & $\mathrm{O} 26: \mathrm{H} 11$ & 13 & $e a e, \alpha-H l y$ & 1981 & Brazil \\
\hline 47 & $\mathrm{O} 26: \mathrm{H} 11$ & 15 & eae, EHEC & 1988 & Brazil \\
\hline $5624-50$ & O55:H7 & 5 & eae & 1950 & USA \\
\hline $660-79$ & O55:H7 & 5 & eae & 1979 & USA \\
\hline $586-65$ & O55:H7 & 5 & eae & 1965 & Sri-Lanka \\
\hline $148-83$ & $\mathrm{O} 55: \mathrm{H} 7$ & 5 & eae & 1983 & Chile \\
\hline $13-81$ & O55:H7 & 5 & eae & 1981 & Brazil \\
\hline $154-11$ & $\mathrm{O} 55: \mathrm{H} 7$ & 5 & eae & 1978 & Brazil \\
\hline 340 & O55:H7 & 5 & eae & 1978 & Brazil \\
\hline 316 & O55:H7 & 5 & eae & 1983 & Brazil \\
\hline 25 & O111ab:H ${ }^{-}$ & 9 & eae & 1983 & Chile \\
\hline 255 & O111ab:H $\mathrm{H}^{-}$ & 9 & eae, $\alpha-H l y$ & 1993 & Brazil \\
\hline 238 & O111ab:H $\mathrm{H}^{-}$ & 9 & eae, $\alpha-H l y$ & ND & Brazil \\
\hline 179 & O111ab:H9 & 9 & eae, $\alpha-H l y$ & 1977 & USA \\
\hline 233 & O111ab:H9 & 9 & $e a e, \alpha-H l y$ & 1993 & Brazil \\
\hline 29 & O111ab:H9 & 9 & eae & 1982 & Brazil \\
\hline 5 & O111ac:H9 & 9 & eae & 1986 & Brazil \\
\hline 50 & O111ac:H9 & 9 & eae & 1981 & Brazil \\
\hline 263 & O111ac:H9 & 9 & eae & 1993 & Brazil \\
\hline 72 & $\mathrm{O} 119: \mathrm{H} 2$ & 7 & $e a e, b f p A^{*}$ & 1993 & Brazil \\
\hline 79 & $\mathrm{O} 119: \mathrm{H} 2$ & 7 & $e a e, b f p A$ & 1993 & Brazil \\
\hline 80 & $\mathrm{O} 119: \mathrm{H} 2$ & 7 & $e a e, b f p A$ & 1993 & Brazil \\
\hline 109 & $\mathrm{O} 119: \mathrm{H} 2$ & 7 & $e a e, b f p A$ & ND & Mexico \\
\hline 112 & O119:H2 & 8 & $e a e, b f p A$ & 1960 & Denmark \\
\hline 118 & $\mathrm{O} 119: \mathrm{H} 2$ & 9 & $e a e, b f p A$ & 1974 & USA \\
\hline
\end{tabular}

ET, electrophoretic type; eae, EPEC attaching and effacing; $\alpha$ - $H l y, \alpha$-haemolysin; EHEC, EHEC plasmid; $b f p A$, bundle-forming pilus. All strains were negative with probes for EAF (EPEC adherence factor), AA (aggregative adherence), DA (diffuse adherence), Inv ( $E$. coli invasiveness), Stx 1 and Stx2 (Shiga toxin 1 and 2), LT-I and LT-II ( $E$. coli enterotoxin type 1 and 2 ), STh (heat-stable enterotoxin $E$. coli of human origin), STp (heat-stable enterotoxin E. coli of porcine origin) and CDT (cytolethal distending toxin); ND, not determined.

${ }^{*}$ BFP is not expressed in these strains as verified by Western blotting with anti-BFP polyclonal serum. 
Table 2. Bacterial strains used as controls and for other purposes in this study

\begin{tabular}{llc}
\hline Strain no. & Description & Reference \\
\hline E2348/69 & $\begin{array}{l}\text { EPEC (O127:H6) isolated from } \\
\text { an outbreak in Taunton, UK } \\
\text { Strain E2348/69 spontaneously } \\
\text { JPN15 }\end{array}$ & {$[24]$} \\
cured of pMAR2 plasmid & {$[8]$} \\
pAC15 (pCVD450) & $\begin{array}{l}\text { pACY 184 vector harbouring } \\
\text { per genes from E2348/69 } \\
\text { eae (intimin) gene deletion } \\
\text { mutant of E2348/69 }\end{array}$ & {$[15]$} \\
CVD206 & $\begin{array}{l}\text { Wild-type EPEC strain } \\
\text { (O114:H2) }\end{array}$ & {$[25]$} \\
ICC61 & & {$[26]$} \\
\hline
\end{tabular}

intimin were used [15]. Intimin type-specific antisera were raised as described previously [14]. A polyclonal antiserum raised against the 280 amino acid C-terminal of the cell-binding domain of intimin from EPEC serotypes O127:H6 (intimin $\alpha$ ) and O114:H2 (intimin $\beta$ ) was used [14].

\section{HEp-2 cell adherence assay}

The ability to adhere to HEp-2 cells was determined as described by Scaletsky et al. [27]. Monolayers were examined after incubation for 3 and $6 \mathrm{~h}$.

\section{Invasion assay}

The invasiveness of bacteria was quantified by the method of Francis et al. [28]. Monolayers of $10^{5} \mathrm{HEp}$ 2 cells in 24-well plates with minimal essential medium (MEM, Sigma) supplemented with fetal bovine serum $10 \%$ were infected with $3 \times 10^{8}$ bacteria. After incubation for $3 \mathrm{~h}$, non-adherent bacteria were removed from the monolayers by washing with phosphate-buffered saline (PBS), pH 7.2. MEM containing gentamicin $100 \mathrm{mg} / \mathrm{L}$ was added to each well for $1 \mathrm{~h}$ to kill any remaining extracellular bacteria. The monolayers were then washed with PBS, and the epithelial cells were lysed with Triton X-100 $1 \%$ for $10 \mathrm{~min}$. Serial dilutions of the resulting suspension were plated on MacConkey agar and the relative number of intracellular bacteria was expressed as the number of cfu of bacteria recovered from the lysed monolayer after treatment with gentamicin for $1 \mathrm{~h}$. All assays were performed in duplicate.

\section{Fluorescent actin staining test}

The fluorescent actin staining (FAS) test, which demonstrates the presence of filamentous actin beneath attached bacteria, was performed as described by Knutton et al. [29]. The strains were tested after incubation for 3 and $6 \mathrm{~h}$.

\section{Transmission electron microscopy}

The association (adherence and invasion) of atypical EPEC with HEp-2 cells was analysed by transmission electron microscopy (TEM) as described by Pedroso et al. [30]. Preparations were fixed for TEM after incubation of bacteria with HEp- 2 cells for $6 \mathrm{~h}$.

\section{Haemolysin assay}

Production of $\alpha$-haemolysin ( $\alpha$-Hly) and enterohaemolysin (E-Hly) was investigated on blood agar as described by Beutin et al. [31] with a heavy streak inoculum. Strains were considered positive for $\alpha$-Hly production when haloes of haemolysis were observed around the growth after incubation for $3 \mathrm{~h}$ and for EHly production only after incubation for $24 \mathrm{~h}$. Hybridisation with a DNA probe for $\alpha$-haemolysin was performed as described by Welch et al. [32].

\section{Toxin production}

All strains were tested for production of cytotoxins active against Vero and HeLa cells [33] and in ligated rabbit ileal loops [34].

\section{Detection of intimin $\alpha, \beta$ and $\gamma$ by PCR and Western blotting}

$P C R$. Table 3 shows the specific forward primers used in the PCR to amplify a segment within the $3^{\prime}$ end of the eae gene encoding the 280 amino acid C-terminal of the cell-binding domain of intimin from EPEC serotypes O127:H6 (intimin $\alpha$ ), O114:H2 (intimin $\beta$ ) and 0157:H7 (intimin $\gamma$ ). These primers were used together with a universal reverse primer (Int-Ru) that was synthesised according to the absolutely conserved and universal amino acid sequence WAAGANKY. Amplification was performed in a Thermal Cycler (Minicycler, MJ Research) for 30 cycles as follows: $95^{\circ} \mathrm{C} 20 \mathrm{~s}, 45^{\circ} \mathrm{C} 1 \mathrm{~min}$ and $74^{\circ} \mathrm{C} 1 \mathrm{~min}$ after denaturation at $95^{\circ} \mathrm{C}$ for $5 \mathrm{~min}$. The reaction conditions were a $50-\mu 1$ reaction mixture of the following constitution: $50 \mathrm{mM} \mathrm{KCl}, 10 \mathrm{mM}$ Tris- $\mathrm{HCl}(\mathrm{pH} 8.3)$, gelatin $0.01 \%$, template DNA $100 \mathrm{ng}, 200 \mu \mathrm{M}$ dNTPs, $1.5 \mathrm{mM} \mathrm{MgCl}_{2}$, 25 pmol of each of the primers (Table 3 ) and $1.5 \mathrm{U} \mathrm{Taq}$ DNA polymerase (Gibco-BRL).

Western blotting. Bacterial whole-cell lysates were electrophoresed in SDS-PAGE 8\% gels as described by Laemmli [35], transferred on to nitrocellulose membranes (BioRad) and immunoblotted according to Towbin et al. [36]. Membranes were blocked overnight in a solution consisting of skimmed milk $3 \%$ in PBS containing Tween $200.5 \%$ (PBST), washed three times with PBST and incubated with polyvalent anti-intimin ( 1 in 2000) or anti-intimin $\alpha$ ( 1 in 750) or anti-intimin

Table 3. List of primers used to classify intimin subtypes

\begin{tabular}{llc}
\hline Primer & Orientation & Sequence \\
\hline Int $\alpha$ & Forward & 5'CCTTAGGTAAGTTAAGT \\
Int $\beta$ & Forward & 5'TAAGGATTTTGGGACCC \\
Int $\gamma$ & Forward & 5'ACAAACTTTGGGATGTTC \\
Int $\mathrm{Ru}$ & Reverse & 5'TTTTACACAARYKGCAWAAGC \\
\hline
\end{tabular}


$\beta$ ( 1 in 5000) sera diluted in PBST for $1 \mathrm{~h}$ at room temperature. The membranes were washed three times with PBST and then incubated for a further $1 \mathrm{~h}$ at room temperature with goat anti-rabbit immunoglobulin G antibodies conjugated to alkaline phosphatase (Sigma). The proteins were detected with nitroblue tetrazolium (NBT) and 5-bromo-4-chloro-3-indolylphosphate (BCIP) (Sigma). As no antiserum was available against intimin $\gamma$, this intimin was detected only by PCR.

\section{Adhesion inhibition assay}

Briefly, $50 \mu \mathrm{l}$ of bacterial cultures grown overnight at $37^{\circ} \mathrm{C}$ in Tryptic Soy Broth (Difico) were pre-incubated with $1 \mathrm{ml}$ of polyvalent anti-intimin antiserum ( 1 in 40 dilution in MEM supplemented with fetal bovine serum $2 \%$ and $\mathrm{D}$-mannose $1 \%$ ) for $1 \mathrm{~h}$ at $37^{\circ} \mathrm{C}$. This mix was added to each well with a monolayer of the HEp-2 cells and the plates were incubated for $6 \mathrm{~h}$ at $37^{\circ} \mathrm{C}$. The cells were then washed with PBS, fixed with methanol and stained for $5 \mathrm{~min}$ with May-Grünwald stain and for $20 \mathrm{~min}$ with Giemsa stain. The effect of antiserum upon EPEC adherence to HEp-2 cells was determined by calculating the percentage of cells with four or more attached bacteria in relation to the control experiment done under the same conditions without pre-incubation with antiserum. At least 300 cells were observed in each experiment.

\section{Results}

\section{Adherence patterns}

Among all strains studied, only two belonging to O55:H7 and O26:H11 serotypes adhered to HEp-2 cells after incubation for $3 \mathrm{~h}$, forming large clusters of adherent bacteria, a pattern termed localised adherence (LA) and which is characteristic of typical EPEC strains (Fig. 1A) [27]. The remaining strains adhered only weakly in the usual 3 -h adhesion test (Fig. 1B). However, after incubation for a further $3 \mathrm{~h}$, these strains showed the LA-like (LAL) pattern described elsewhere [20] (Fig. 1C).

\section{Invasion assay}

When atypical strains were analysed for invasive properties all strains invaded HEp-2 cells, although with less efficiency than strain E2348/69. However, no significant differences were seen between the strains studied. The number of bacteria recovered (by plating) from HEp-2 cells after incubation with gentamicin ranged from $10^{3}$ to $10^{5} \mathrm{cfu} / \mathrm{ml}$ (data not shown).

\section{FAS test}

With the exception of two strains (nos. 15 and 20), all were FAS positive after incubation for 3 or $6 \mathrm{~h}$.
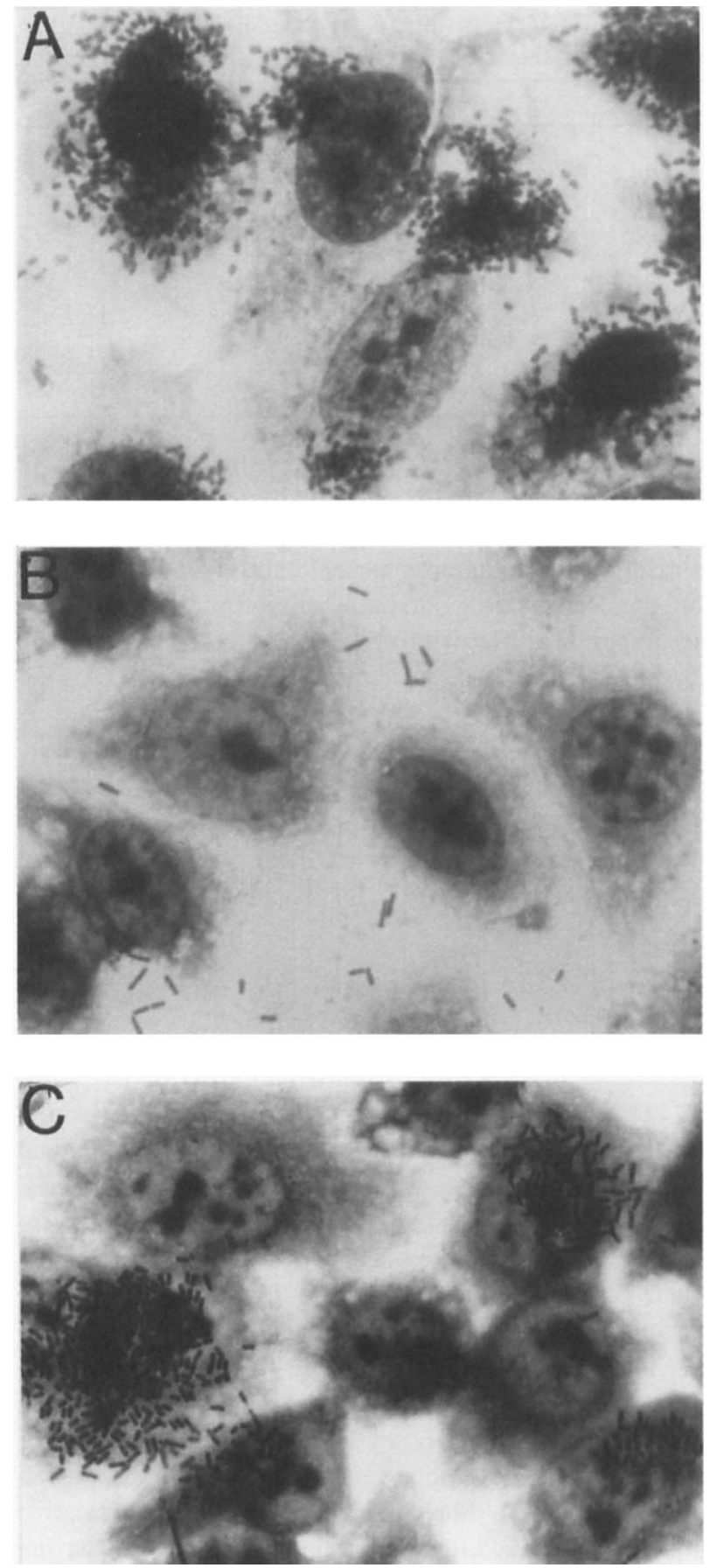

Fig. 1. (A) E. coli $\mathrm{O} 26$ strain 47 showing a LA pattern after incubation for $3 \mathrm{~h}(\times 4000)$. (B) E. coli O111ab:H9 strain 50 showing a non-characteristic adherence pattern after incubation for $3 \mathrm{~h}(\times 3570)$. (C) The same strain showing a LAL pattern after incubation for $6 \mathrm{~h}(\times 3525)$.

\section{Electron microscopy}

Examination of HEp-2 cells by electron microscopy after incubation with bacterial cells for $6 \mathrm{~h}$ at $37^{\circ} \mathrm{C}$ showed characteristic $\mathrm{A} / \mathrm{E}$ lesions, i.e., effacement of microvilli, and cup and pedestal formation at sites of bacterial attachment (Fig. 2A and B). Bacteria were frequently seen enclosed in membrane-bound vacuoles (Fig. 2B), confirming the invasive features demonstrated by the HEp-2 cell gentamicin invasion assay. 

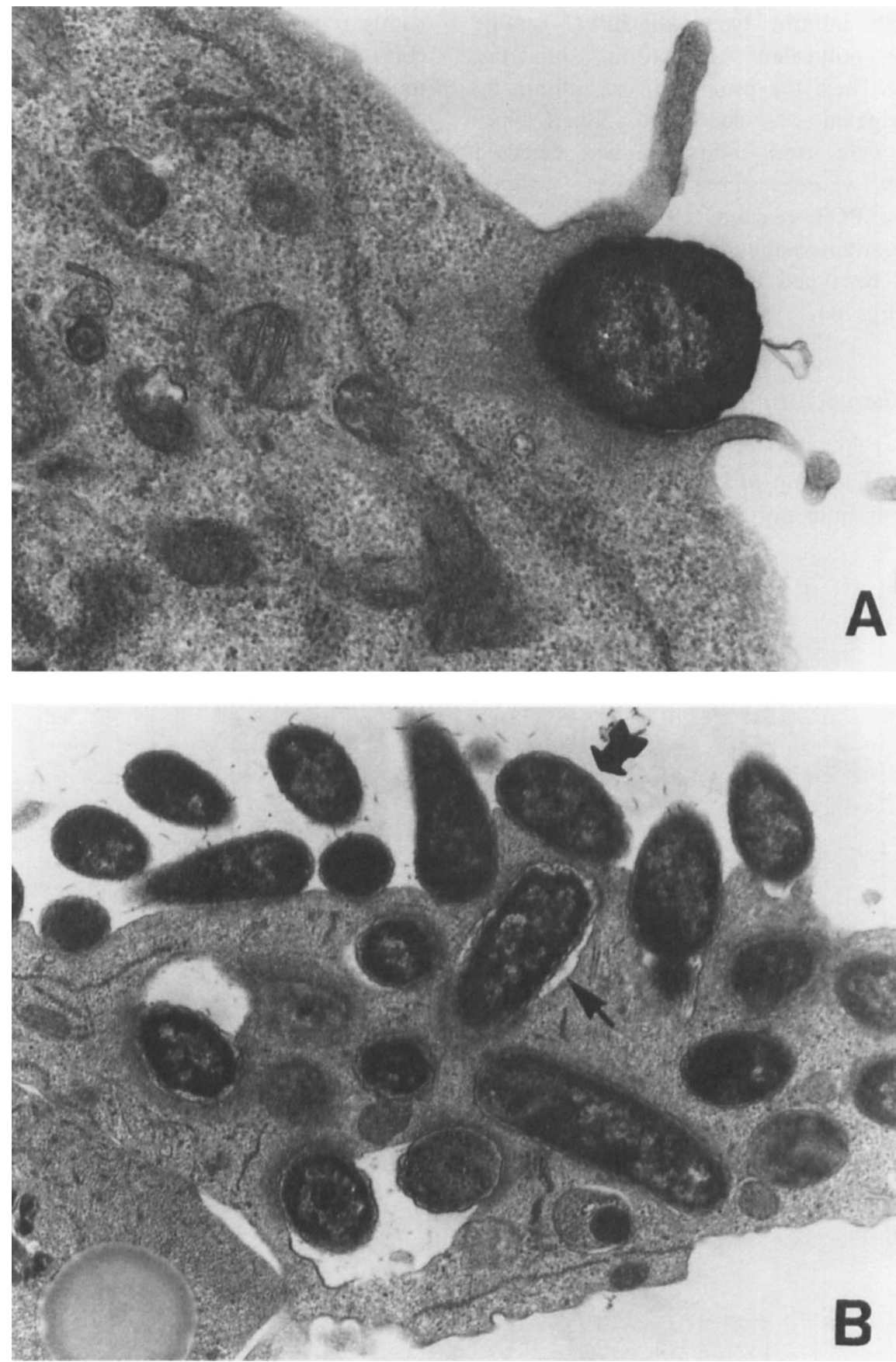

Fig. 2. Electron micrography of HEp-2 cells after incubation for $6 \mathrm{~h}$ at $37^{\circ} \mathrm{C}$ with E. coli O111ac:H9 strain 263 . (A) Bacteria are seen closely adhering to the cell membrane, causing effacement of microvilli and pedestal formation at the sites of attachment. (B) Bacterial cells can be seen closely adhering on surface of epithelial cell ( $\boldsymbol{A}$ ) and enclosed in membrane-bound vacuole $(\rightarrow)$. Magnification: A, $\times 32600$; B, $\times 17140$.

\section{Haemolytic activity}

The five $\mathrm{O} 26$ strains that reacted with the $\alpha$-Hly probe produced $\alpha$-Hly within $3 \mathrm{~h}$ of incubation. Three $\mathrm{O} 26$ and four O111 strains produced haemolysis only after incubation for $24 \mathrm{~h}$ and the latter, but not the former, reacted with the $\alpha$-Hly probe.

\section{Toxin production}

None of the 31 strains had any effect in Vero or HeLa cells or provoked fluid accumulation in the rabbit intestinal loop assay.
Detection of intimin $\alpha, \beta$ and $\gamma$

Amplification of intimin genes $(\alpha, \beta$ and $\gamma)$ of different EPEC serotypes with specific primers revealed that only E2348/69 contained intimin $\alpha$, whereas all strains from serotypes $\mathrm{O} 26: \mathrm{H} 11, \mathrm{O} 26: \mathrm{H}^{-}, \mathrm{O} 119: \mathrm{H} 2$ and O114:H2 contained intimin $\beta$. Strains belonging to $\mathrm{O} 55: \mathrm{H} 7$ were specifically amplified with the intimin $\gamma$ primer. None of the strains from serogroup 0111 gave amplification products with any of the primers specific for intimin $\alpha, \beta$ and $\gamma$ genes, suggesting that these strains may contain a different intimin type. 
Regardless of the intimin type, all EPEC strains reacted with the polyvalent anti-intimin antiserum (data not shown). Thus, the production of intimin by all strains investigated was confirmed. When typespecific antisera were used, intimin $\alpha$ was detected only in E2348/69, whereas strains that were positive for intimin $\beta$ by $\mathrm{PCR}$ reacted with anti-intimin $\beta$ antibodies. Those strains belonging to serogroup $\mathrm{O} 111$ which could not be typed by PCR did not show a typable intimin (Fig. 3).

\section{Inhibition of adherence by polyvalent anti-intimin antiserum}

The participation of intimin in LAL was supported by the fact that anti-intimin polyvalent antiserum signifi- cantly reduced the level of LAL of all strains studied (Fig. 4). As this antiserum is raised against the whole intimin molecule of JPN15, a slightly higher inhibition of adherence was observed in this strain. The preimune rabbit serum did not show any inhibition of the LAL phenotype. Although the results were reported in terms of the reduced number of HEp- 2 cells with attached bacteria, the cluster size was greatly reduced after serum treatment (Fig. 5).

\section{Discussion}

The results obtained show that 29 of the 31 strains exhibited the LAL adherence pattern and two exhibited an adherence pattern similar to LA. The reason for this

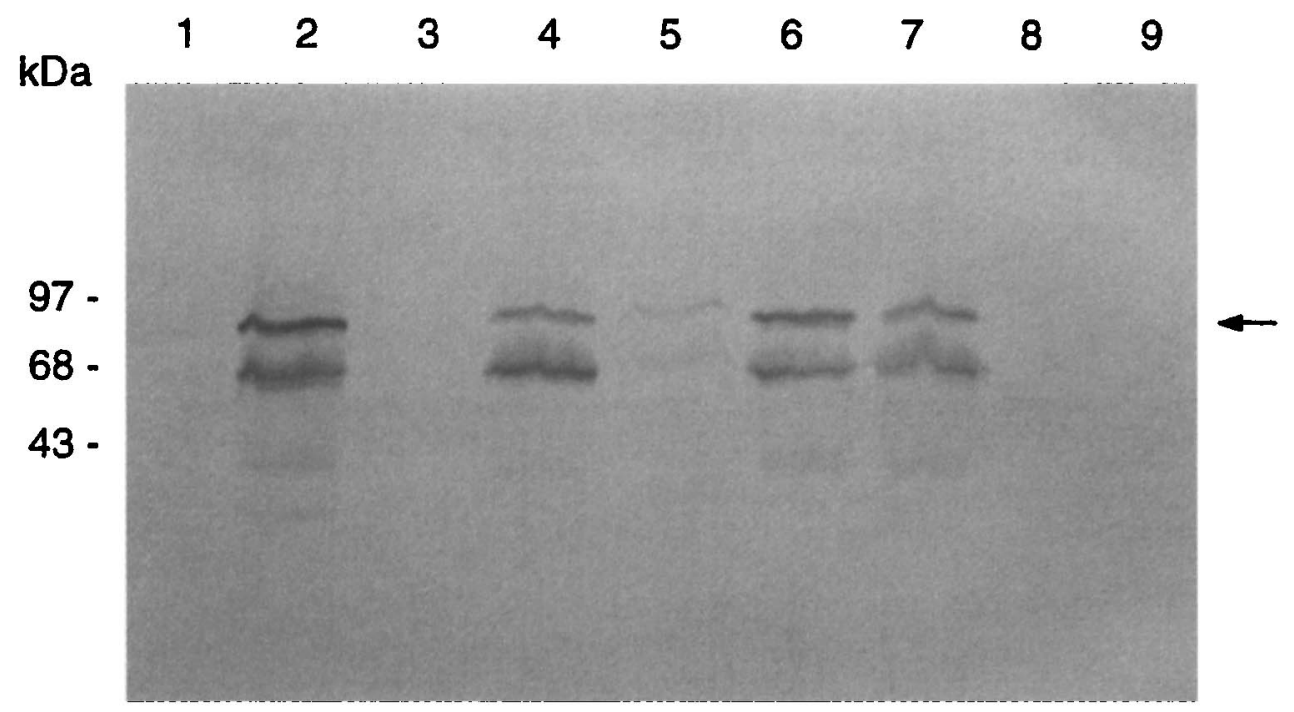

Fig. 3. Western blot analysis of various EPEC strains with intimin $\beta$ antiserum. Anti-intimin $\beta$ was used at a dilution of 1 in 5000. Mol. wt markers $(\mathrm{kDa})$ are shown on the left. Strains E2348/69 (lane 1); ICC61 (2); CVD206 (3); 47 (O26:H11) (4); 20 (O26:H11) (5); 3323-61 (O26:H11) (6); 72 (O119:H2) (7); C586-65 (O55:H7) (8); 263 (O111 ac:H9) $(9) ;(\leftarrow)$ intimin $\beta$.

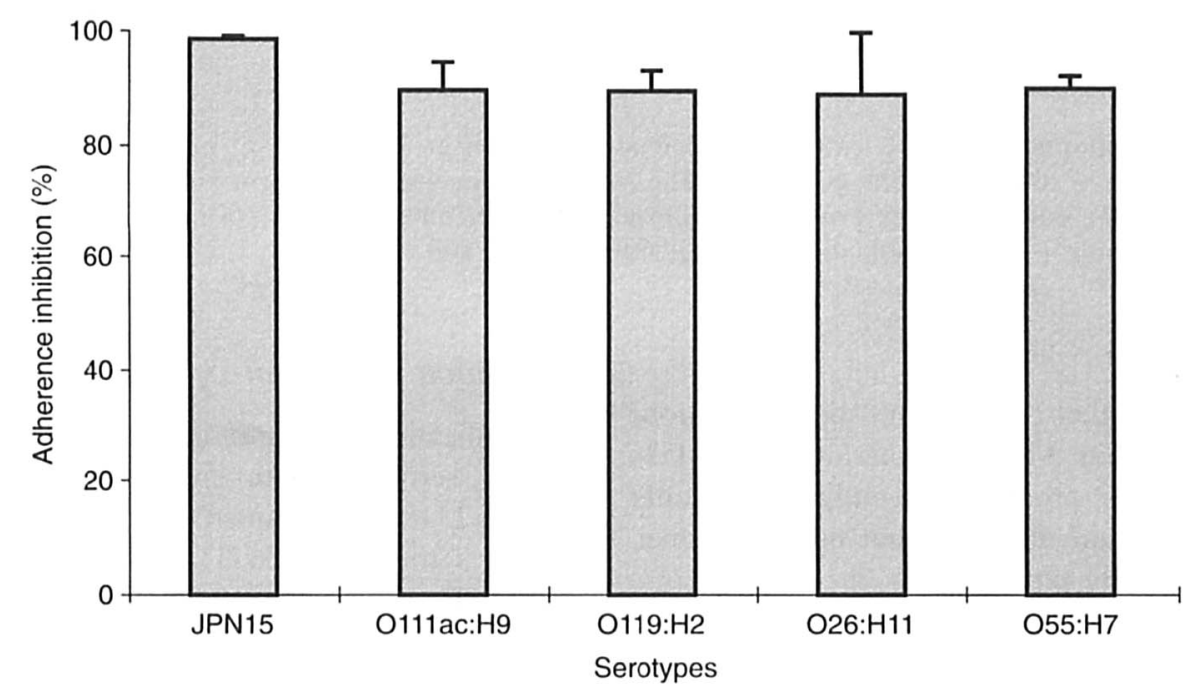

Fig. 4. The effect of the polyvalent anti-intimin serum on LAL E. coli adherence was determined by calculating the percentage of cells with five or more attached bacteria in relation to the control performed with PBS. Values are means and SEM from three experiments. 

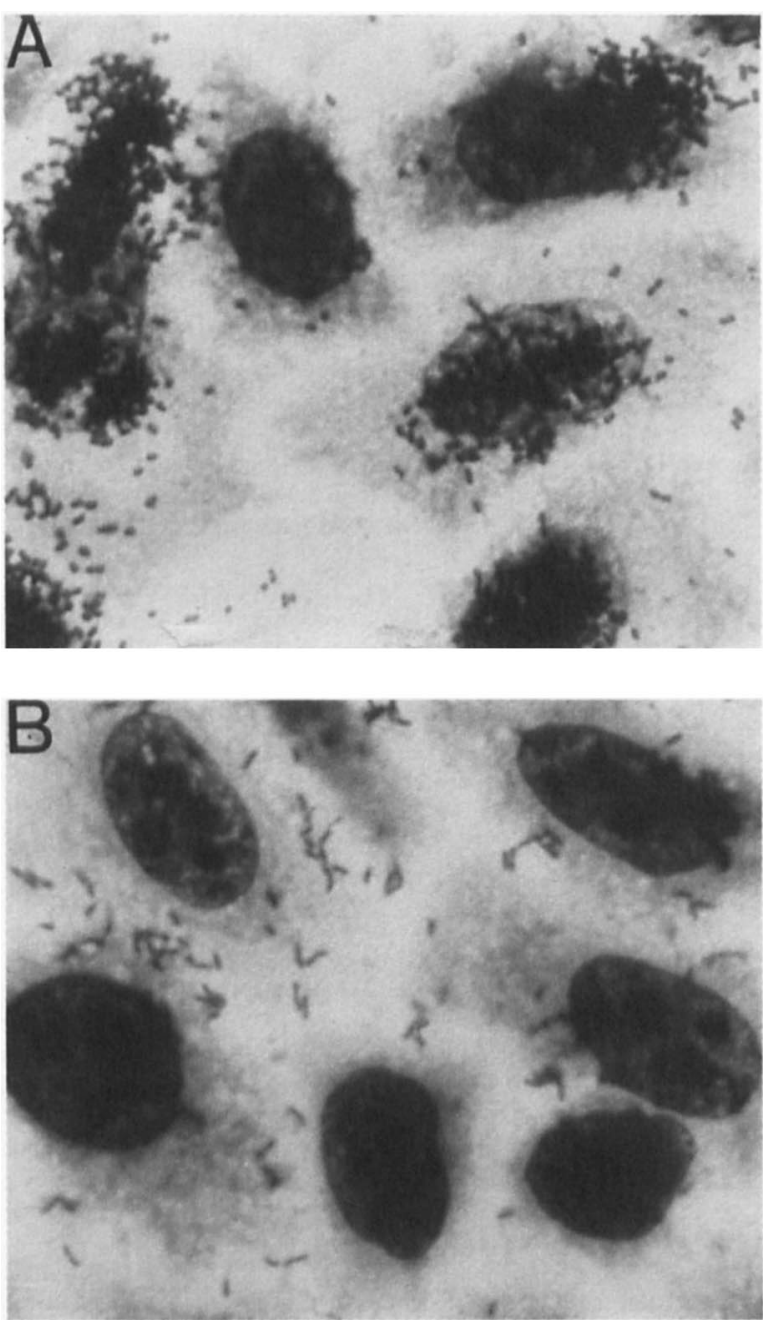

Fig. 5. Adherence of E. coli O119:H2 strain 72 to HEp-2 cells in the absence (A) and in the presence of polyvalent anti-intimin serum after incubation for $6 \mathrm{~h}$ (B). Magnification: A, $\times 4280 ; \mathrm{B}, \times 4320$.

difference was not investigated, but it is probable that these LA strains have adhesins not present in the other strains. Regarding the LAL strains, it has been generally accepted that the adhesion of EPEC strains to cultured epithelial cells is mediated initially by bundle-forming pili (BFP) and later by intimin $[8,16]$. There is also evidence that the aggregation of the bacterial cells to form the LA cluster on the surface of the cultured epithelial cell is mediated by BFP. As all 29 LAL strains lacked BFP, it is likely that the delayed appearance and the weaker density of this pattern are due to the lack of BFP production by these strains. On the other hand, as all the strains produced intimin and a polyvalent anti-intimin serum substantially reduced the LAL pattern, it is probable that this pattern is mediated at least partially by intimin. The absence of BFP may also explain why the strains were less invasive than the control strain (E2348/69) and why some strains showed a positive FAS test only after incubation for $6 \mathrm{~h}$. Furthermore, these results, as well as the LAL pattern, may have been influenced by the fact that the O26, O55 and O111 strains did not have per genes. In a recent study, Knutton et al. [37] showed that the presence of the per genes encoded by the EAF plasmid was responsible for the increased number of EPEC cells expressing surface intimin during the logarithmic growth phase. It is in accordance with this fact that the six O119:H2 strains that are per positive had a positive FAS test in $3 \mathrm{~h}$.

The haemolytic pattern exhibited by the strains was interesting. The $\mathrm{O} 26$ strains that reacted with the $\alpha$ Hly probe were haemolytic within $3 \mathrm{~h}$ of incubation and so clearly produced the classical $E$. coli $\alpha$-Hly. In contrast, the 0111 strains that were positive with the $\alpha$-Hly probe were haemolytic only after $24 \mathrm{~h}$, which indicates that these strains may have had secretion dysfunction of $\alpha$-Hly or were producing an enterohaemolysin-like substance. In view of their probe positivity, the former explanation seems more likely. Three O26 strains, which were negative for $\alpha$-Hly probe, were positive for E-Hly.

None of the 31 strains of $E$. coli displayed a cytotoxic effect in HeLa and Vero cells or provoked fluid accumulation in the rabbit intestinal loop assay.

Only eae positive strains were included in this study [19-22]. With an anti-intimin polyclonal antiserum, Western blotting confirmed that all the strains expressed intimin. The N-termini of cloned intimin polypeptides have been shown to be highly conserved, whereas the C-termini are considerably more variable $[10,13]$. Frankel et al. [13] reported that the binding domain of intimin resides in the $\mathrm{C}$-terminus. On the basis of the variation within the cell-binding domain Adu-Bobie et al. [14] have recently subtyped the intimin family into groups designated $\alpha, \beta, \gamma$ and $\delta$.

In the present study, PCR and Western blotting were used to study the antigenic variation within the cellbinding domain of intimin expressed by the atypical EPEC strains. In agreement with Adu-Bobie et al. [14], with PCR primers designed on the basis of the eae sequences of EPEC strains O127:H6 (intimin $\alpha$ ), O114:H2 (intimin $\beta$ ) and O157:H7 (intimin $\gamma$ ), only E2348/69 (O127:H6) was found to have intimin $\alpha$, whereas all the strains belonging to serotypes $\mathrm{O} 26: \mathrm{H} 11, \mathrm{O} 26: \mathrm{H}^{-}, \mathrm{O} 119: \mathrm{H} 2$ and ICC61 (O114:H2) expressed intimin $\beta$. The eight strains of serotypes O55:H7 harboured intimin $\gamma$. The strains of serogroup O111 tested had a non-typable intimin, suggesting that there are still other intimin types yet to described. The strains that produced a specific PCR product with the intimin $\alpha$ or intimin $\beta$ primers also were recognised by anti-intimin $\alpha$ or anti-intimin $\beta$ in Western blotting.

The production of intimin $\gamma$ by the $055: \mathrm{H} 7$ strains reinforces the phylogenetic similarity between this serotype and serotype $\mathrm{O} 157: \mathrm{H} 7$ [38] and the failure of the atypical 0111 strains to produce intimin $\beta$ represents an additional difference between the 
atypical and the typical 0111 strains, because the latter produce intimin $\beta$ [14].

From the whole series of results, it may be concluded that most atypical EPEC and typical EPEC strains have similar virulence properties, with the exception of those coded by the EAF plasmid. The behaviour of the $\mathrm{O} 119: \mathrm{H} 2$ strains probably is also due to the nonproduction of the BFP. However, studies under way in this laboratory suggest that most atypical EPEC strains have the ast $A$ gene encoding EAST-1 toxin while the typical ones do not [39].

Regarding the capacity of atypical EPEC to cause diarrhoea, more studies are necessary to elucidate their virulence mechanisms. However, volunteer studies performed by Levine et al. [40] have shown that JPN15 (a plasmid-less EPEC strain) caused diarrhoea, but less severely than the wild-type strain. Thus, it is probable that atypical EPEC lacking plasmid-encoded determinants also have the ability to cause diarrhoea. This hypothesis is reinforced by the fact that these atypical EPEC have been isolated from individuals with diarrhoea in which no other pathogen can be identified [23].

This work was supported by grants 41.96.08881.00 (FINEP/MCT/PRONEX) and 96/4148-5 (FAPESP) awarded to L.R.T.

\section{References}

1. McDaniel TK, Jarvis KG, Donnenberg MS, Kaper JB. A genetic locus of enterocyte effacement conserved among diverse enterobacterial pathogens. Proc Natl Acad Sci USA 1995; 92: 1664-1668.

2. McDaniel TK, Kaper JB. A cloned pathogenicity island from enteropathogenic Escherichia coli confers the attaching and effacing phenotype on E. coli K-12. Mol Microbiol 1997; 23: 399-407.

3. Jarvis KG, Girón JA, Jerse AE, McDaniel TK, Donnenberg MS and Kaper JB. Enteropathogenic Escherichia coli contains a putative type III secretion system necessary for the export of proteins involved in attaching and effacing lesion formation. Proc Natl Acad Sci USA 1995; 92: 7996-8000.

4. Donnenberg MS, Yu J, Kaper JB. A second chromosomal gene necessary for intimate attachment of enteropathogenic Escherichia coli to epithelial cells. J Bacteriol 1993; 175: 4670-4680.

5. Kenny B, Lai LC, Finlay BB, Donnenberg MS. EspA, a protein secreted by enteropathogenic Escherichia coli, is required to induce signals in epithelial cells. Mol Microbiol 1996; 20: 313-323.

6. Lai L-C, Wainwright LA, Stone KD, Donnenberg MS. A third secreted protein that is encoded by the enteropathogenic Escherichia coli pathogenicity island is required for transduction of signals and for attaching and effacing activities in host cells. Infect Immun 1997; 65: 2211-2217.

7. Jerse A E, Kaper JB. The eae gene of enteropathogenic Escherichia coli encodes a 94-kilodalton membrane protein, the expression of which is influenced by the EAF plasmid. Infect Immun 1991; 59: 4302-4309.

8. Jerse AE, Yu J, Tall BD, Kaper JB. A genetic locus of enteropathogenic Escherichia coli necessary for the production of attaching and effacing lesion on tissue culture cells. Proc Natl Acad Sci USA 1990; 87: 7839-7843.

9. Beebakhee G, Louie M De, Azevedo J, Brunton J. Cloning and nucleotide sequence of the eae gene homologue from enterohemorrhagic Escherichia coli serotype O157:H7. FEMS Microbiol Lett 1992; 91: 63-68.
10. Yu J, Kaper JB. Cloning and characterization of the eae gene of enterohemorrhagic Escherichia coli O157:H7. Mol Microbiol 1992; 6: 411-417.

11. Frankel G, Candy DCA, Everest P, Dougan G. Characterization of the C-terminal domains of intimin-like proteins of enteropathogenic and enterohemorrhagic Escherichia coli, Citrobacter freundii, and Hafnia alvei. Infect Immun 1994; 62: 1835-1842.

12. Schauer DB, Falkow S. Attaching and effacing locus of a Citrobacter freundii biotype that causes transmissible murine colonic hyperplasia. Infect Immun 1993; 61: 2486-2492.

13. Frankel G, Candy DCA, Fabiani E et al. Molecular characterization of a carboxy-terminal eukaryotic-cell-binding domain of intimin from enteropathogenic Escherichia coli. Infect Immun 1995; 63: 4323-4328.

14. Adu-Bobie J, Frankel G, Bain C et al. Detection of intimins alpha, beta, gamma and delta: four intimin derivatives expressed by attaching and effacing microbial pathogens. J Clin Microbiol 1998; 36: 662-668.

15. Gómez-Duarte OG, Kaper JB. A plasmid-encoded regulatory region activates chromosomal eaeA expression in enteropathogenic Escherichia coli. Infect Immun 1995; 63: 1767-1776.

16. Girón JA, Ho ASY, Schoolnik GK. An inducible bundle-forming pilus of enteropathogenic Escherichia coli. Science 1991; 254: 710-713.

17. Knutton S, Baldini MM, Kaper JB, McNeish AS. Role of plasmid-encoded adherence factors in adhesion of enteropathogenic Escherichia coli to HEp-2 cells. Infect Immun 1987; 55: 78-85.

18. Kaper JB. Defining EPEC. Rev Microbiol 1996; 27 Suppl 1: 130-133.

19. Saridakis HO. Non production of Shiga-like toxins by Escherichia coli serogroup O26. Rev Microbiol 1994; 25: 154-155.

20. Rodrigues J, Scaletsky ICA, Campos LC, Gomes TAT, Whittam TS, Trabulsi LR. Clonal structure and virulence factors in strains of Escherichia coli of the classic serogroup 055. Infect Immun 1996; 64: 2680-2686.

21. Campos LC, Whittam TS, Gomes TAT, Andrade JRC, Trabulsi LR. Escherichia coli serogroup O111 includes several clones of diarrheagenic strains with different virulence properties. Infect Immun 1994; 62: 3282-3288.

22. Gonçalves AG, Campos LC, Gomes TAT et al. Virulence properties and clonal structures of strains of Escherichia coli O119 serotypes. Infect Immun 1997; 65: 2034-2040.

23. Scotland SM, Smith HR, Said B, Willshaw GA, Cheasty T, Rowe B. Identification of enteropathogenic Escherichia coli isolated in Britain as enteroaggregative or as members of a subclass of attaching-and-effacing $E$. coli not hybridising with the EPEC adherence factor probe. J Med Microbiol 1991; 35: $278-283$.

24. Levine MM, Bergquist EJ, Nalin DR et al. Escherichia coli strains that cause diarrhoea but do not produce heat-labile or heat-stable enterotoxins and are non-invasive. Lancet 1978; 1: 1119-1122.

25. Donnenberg MS, Kaper JB. Construction of an eae deletion mutant of enteropathogenic Escherichia coli by using a positiveselection suicide vector. Infect Immun 1991; 59: 4310-4317.

26. Hill SM, Phillips AD, Walker-Smith JA. Enteropathogenic Escherichia coli and life threatening chronic diarrhoea. Gut 1991; 32: $154-158$.

27. Scaletsky ICA, Silva MLM, Trabulsi LR. Distinctive patterns of adherence of enteropathogenic Escherichia coli to HeLa cells. Infect Immun 1984; 45: 534-536.

28. Francis CL, Jerse AE, Kaper JB, Falkow S. Characterization of interactions of enteropathogenic Escherichia coli O127:H6 with mammalian cells in vitro. J Infect Dis 1991; 164: 693-703.

29. Knutton S, Baldwin T, Williams PH, McNeish AS. Actin accumulation at sites of bacterial adhesion to tissue culture cells: basis of a new diagnostic test for enteropathogenic and enterohemorrhagic Escherichia coli. Infect Immun 1989; 57: 1290-1298

30. Pedroso MZ, Freymüller E, Trabulsi LR, Gomes TAT. Attachingeffacing lesions and intracellular penetration in HeLa cells and human duodenal mucosa by two Escherichia coli strains not belonging to the classical enteropathogenic $E$. coli serogroups. Infect Immun 1993; 61: 1152-1156.

31. Beutin L, Prada J, Zimmermann S, Stephan R, Ørskov I, Ørskov F. Enterohemolysin, a new type of hemolysin produced by some strains of enteropathogenic E. coli (EPEC). Zentralbl Bakteriol Mikrobiol Hyg A 1988; 267: 576-588. 
32. Welch RA, Hull R, Falkow S. Molecular cloning and physical characterization of a chromosomal hemolysin from Escherichia coli. Infect Immun 1983; 42: 178-186.

33. Konowalchuk J, Speirs JI, Stavric S. Vero response to a cytotoxin of Escherichia coli. Infect Immun 1977; 18: 775-779.

34. Moon HW, Whipp SC, Argenzio RA, Levine MM, Giannella RA. Attaching and effacing activities of rabbit and human enteropathogenic Escherichia coli in pig and rabbit intestines. Infect Immun 1983; 41: 1340-1351.

35. Laemmli UK. Cleavage of strutural proteins during the assembly of the head of bacteriophage T4. Nature 1970; 227: 680-685.

36. Towbin H, Staehelin T, Gordon J. Electrophoretic transfer of proteins from polyacrylamide gels to nitrocellulose sheets: procedure and some applications. Proc Natl Acad Sci USA 1979; 76: 4350-4354

37. Knutton S, Adu-Bobie J, Bain C, Phillips AD, Dougan G,
Frankel G. Down regulation of intimin expression during attaching and effacing enteropathogenic Escherichia coli adhesion. Infect Immun 1997; 65: 1644-1652.

38. Whittam TS, Wolfe ML, Wachsmuth IK, Ørskov F, Ørskov I, Wilson RA. Clonal relationships among Escherichia coli strains that cause hemorrhagic colitis and infantile diarrhea. Infect Immun 1993; 61: 1619-1629.

39. Sousa CP, Campos LC, Trabulsi LR. Frequency of the astA gene (EAST-1 toxin) in strains of different serotypes of diarrheagenic Escherichia coli. In: General Meeting of the American Society for Microbiology, 97. Miami Beach, American Society for Microbiology, 1997. Abstract B-252: p. 72

40. Levine MM, Nataro JP, Karch $\mathrm{H}$ et al. The diarrheal response of humans to some classic serotypes of enteropathogenic Escherichia coli is dependent on a plasmid encoding enteroadhesiveness factor. $J$ Infect Dis 1985 ; 152: 550-559. 